\title{
FLIPPED CLASSROOM MODEL: EMPOWERING DIGITAL LITERACY FOR MATHEMATICS LEARNING IN SOCIETY 5.0
}

\author{
Wanda Nugroho Yanuarto ${ }^{1 *}$, Anton Jaelani ${ }^{2}$, Joko Purwanto ${ }^{3}$ \\ ${ }^{1,2,3}$ Mathematics Education, Teacher Training and Education, Universitas Muhammadiyah Purwokerto, \\ Indonesia
}

*Corresponding author: wandanugrohoyanuarto@ump.ac.id

\begin{tabular}{l}
\hline \hline Article Info \\
\hline Article history: \\
Received: June 04, 2021 \\
Accepted: July 05, 2021 \\
Published: July 31, 2021
\end{tabular}

\section{Keywords:}

Digital literacy

Flipped classroom model

Mathematics learning

Society 5.0

\begin{abstract}
In the era of society 5.0, technology and education are likely two side of coin. Teachers can use technology in the classroom. Also, teachers play a role in maximizing the quality of learning. This study employed descriptive qualitative research. This study aimed produced an overview of flipped classroom used in learning activities, particularly in learning mathematics. The research data in this study were observations, semi-structure interviews, and documentation of flipped classroom learning activities. The research subjects were 37 seventh-grade students of one of junior high school in Purwokerto, Indonesia. The data analysis technique in this study consisted of four stages:1) data collection, 2) data reduction, 3) data presentation and 4) drawing conclusions. The results of this study are: 1) flipped classroom improves teachers and students digital literacy; 2) flipped classroom as one alternative learning model; 3) flipped classroom expressed students' positive activities with technology; and 4) flipped classroom provide opportunities for parents interact with students in home activities.
\end{abstract}

\section{MODEL FLIPPED CLASSROOM: MEMBERDAYAKAN LITERASI DIGITAL UNTUK PEMBELAJARAN MATEMATIKA PADA MASYARAKAT 5.0}

\section{Kata Kunci: \\ Literasi digital \\ Model flipped classroom \\ Pembelajaran matematika \\ Masyarakat 5.0}

\section{ABSTRAK}

Pada era masyarakat 5.0 ini, teknologi dan pendidikan bagaikan dua sisi mata uang. Guru dapat menggunakan teknologi di kelas. Tujuan artikel ini adalah menggambarkan aktivitas siswa pada model flipped classroom di pembelajaran matematika. Data penelitian ini didapatkan dari hasil observasi, wawancara semi-struktur, dan dokumentasi aktivitas pembelajaran. Subjek penelitian ini sebanyak 37 siswa kelas tujuh salah satu SMP di Purwokerto, Indonesia. Analisis data didasarkan atas empat tahap, yaitu 1) pengambilan data, 2) reduksi data, 3) presentasi data, dan 4) pengambilan kesimpulan. Hasil dari penelitian ini bahwa flipped classroom: 1) mendorong literasi digital guru dan siswa; 2) merupakan salah satu alternatif model pembelajaran; 3) memberikan aktivitas positif menggunakan teknologi; dan 4) memberikan kesempatan orang tua untuk dapat berinteraksi dengan siswa selama aktifitas di rumah. 


\section{INTRODUCTION}

Nowadays, the education has challenges in dealing with the changes of technology. The function of technology in education, for instance teachers used technology to assist learning in classroom and assist the administration [1], therefore, teachers should learn technology in classroom learning. Also, teachers are able to provide learning materials and collaborate with technology [2]. Inspiring students to use technology in learning activities as well [3]. According to Narvaez et al. [4], The role of education in facing the era of society 5.0; they are adaptation and competence. The adaptation process needs to pay attention to the development of students [5] The result of students can transform human civilization [6]. Furthermore, the element of teachers' competition in the society 5.0 era are $4 \mathrm{C}$ skills; creativity, critical thinking, communication, and collaboration [7]. Moreover, 4C competencies can help implement technology for learning [8].

Regarding to Supendi and Nurjanah [9], among the 4Cs teachers, collaboration is one of the most important. The collaboration element gives teachers the ability to use technology in the classroom. The use of technology in education is a basic need for learning in today's era [10]. Furthermore, teachers must allow students in making changes in thinking, such as making their own decisions, innovation in finding learning resources, and learning autonomy [11]. In addition, there are three elements in the era of society 5.0; the internet on things in all school activities, the use of virtual learning, and the use of artificial intelligence technology to support the quality of education [12].

The use of these three elements must be adjusted to the teachers' digital literacy skills (See the figure 1) [13]. First, digital literacy can identify technology-based learning needs [10]. According to Fatahillah et al. [14], digital literacy combines the ability to use technology, critical thinking, and collaboration skills between education and technology in the classroom. The use of technology in learning is the availability of online media that can assist in learning activities. Online media helpful in supporting learning activities, including zoom meetings, google meet, YouTube, and others [15]. Digital literacy plays a role in maximizing the media [16]. Digital literacy also supervises in students' technology activities [17]. It can be said that technology plays a positive role in student learning activity [11]. With digital literacy, students can sort out good information as a learning resource and eliminate the opposing sides of technology, such as lack of social interaction and health problems [18]. Therefore, it is necessary to have an awareness of mastering digital literacy for teachers and students to support the quality of education in these technological eras.

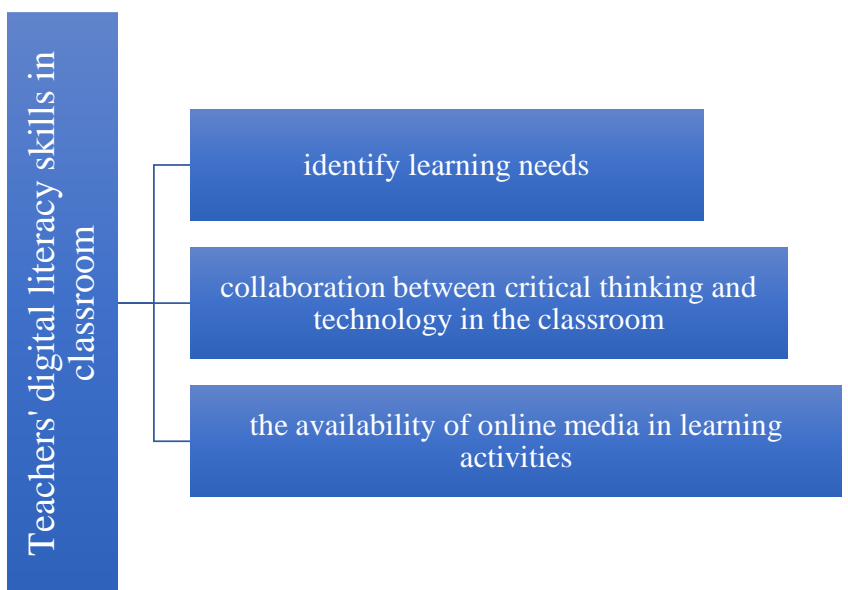

Figure 1. Digital Literacy Skills for Teachers in Classroom 
In addition, teachers also play a role in maximizing the quality of learning by using technology [4]. Besides, based on Lo and Hew [19], quality of learning in today's technology era is the flipped classroom. Flipped classroom model can collaborate student activities in class and at home [20]. In this case, the role of teachers is as a mediator and supervisor use of technology in flipped activities [13]. In addition, the use of online media can help improve student learning activities [20]. Teachers can add the material into the online media and ask students to learn [21]. At the same time, teachers can also assess students' home activities through the assignment system [22]. Subsequently, the following process is class activities; teachers discuss the material with the students and students' presentation activities. Also, flipped classroom in the technology era represents in a virtual class [23]. The virtual learning assisted by utilizing technology applications, such as zoom meetings, google classroom, and others [24]. Unfortunately, the previous research only stated the flipped classroom in classroom by technology. The students' activities haven't occurred in their study. So, in this study we employed not only the flipped classroom learning material, but also, students' activeness in virtual class. Therefore, we believed that our study can state with the technology, and students' activities still occur, such as learn the material and find learning resources.

\section{METHOD}

This study employed descriptive qualitative research. According to Creswell [26], descriptive qualitative research is used to analyze events or phenomena in the surrounding environment. In this study, we interested in exploring the change of teachers and students' activities in flipped classroom model. It has an impact on the implementation of learning in the classroom. The flipped classroom model is the answer to the problems that occur in the technology era. This study aimed produced an overview of flipped classroom used in learning activities, especially in learning mathematics. According to Cohen et al. [27], qualitative descriptive research provided an overview of written or oral data and observable behaviors. In this study, the data were about teachers and students' activities in flipped classroom learning.

The research subjects in this study were 37 students of seventh-grade students of Muhammadiyah 1 Secondary School, Purwokerto, Indonesia, the detail for research subject was pointing in Table 1 .

Table 1. Research Subject

\begin{tabular}{ccc}
\hline Category & Detail & Respondent \\
\hline Gender & Male & 19 \\
& Female & 18 \\
Age & 13 & 6 \\
& 14 & 25 \\
Frequently using & 15 & 6 \\
technology per day & $<3$ hours & 10 \\
& $3-5$ hours & 18 \\
& $>5$ hours & 9 \\
\hline
\end{tabular}

The research data in this study were observations, semi-structure interviews, and documentation of flipped classroom learning activities. Data analysis in this study obtained from the results of flipped classroom learning activities, then developed into patterns and hypotheses to answer problems. The data analysis technique in this study consists of four stages:1) data collection, 2) data reduction, 3) data presentation and 4) drawing conclusions [30] (See Figure 2). The initial process is carried out by collecting data that has been done utilizing observation, interviews and documentation of learning activities. 


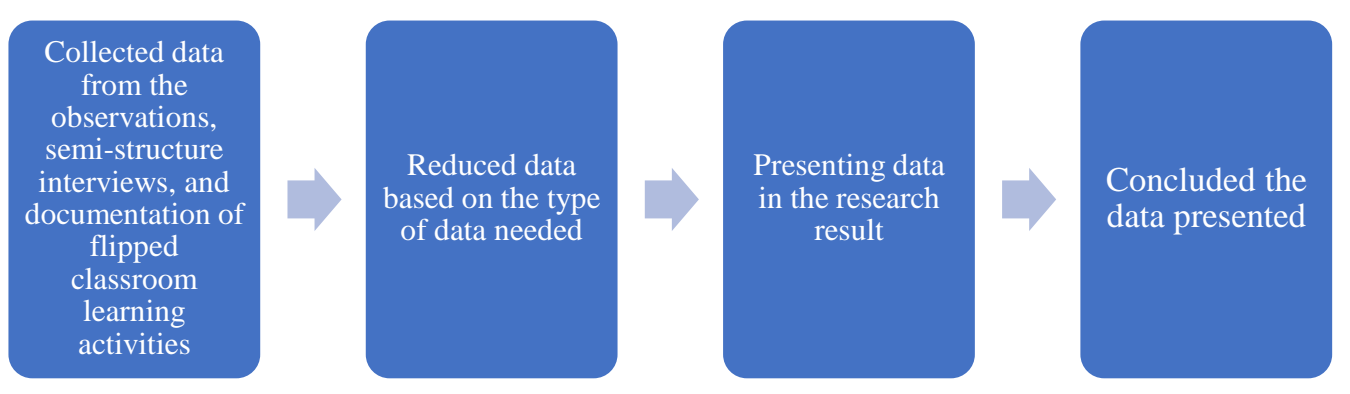

Figure 2. Data Analysis Technique

Furthermore, the collected data was reduced based on the type of data needed. The required data used as primary data, then presented in the research results. According to Cohen et al. [27], the process of giving information is adjusted to the research objectives that have been set. The final stage in this study was concluded the data presented. The process of inferring the data in this study used a peer debriefing technique: obtaining conclusions from several experts who are competent in descriptive qualitative research [27].

\section{RESULT AND DISCUSSION}

\subsection{Teachers Activities in Flipped Classroom Activities}

Teachers' activities in flipped classroom consist of:1) preparing students and parents; 2) preparing learning materials; 3) delivering learning concepts; 4) monitoring; 5) elaboration and exploration; and 6) evaluation. The detail information are follows.

\subsubsection{Students and Parents Preparation}

Students and parents required the rules of learning using a flipped classroom. It aims to get cooperation among teachers, students, and parents. The flipped classroom requires the attention of many parties [28]. Moreover, whereas students' activities at home and in class needs a focus on it. According to Hidayah and Mustadi [29], while studying at home, students are obliged to learn the concept material given by the teacher. Meanwhile, during class activities, students actively participate during presentations and discussions [30].

On the other way, learning autonomy was students' competence that must be possessed during the flipped classroom [31]. Students may make their study plans and solutions with their methods and thinking [32]. Additionally, the role of parents as supervisors in learning activities at home with the teacher's guidance [33]. According to Lestari and Noer [34], flipped classroom provides an opportunity for parents have a quality time with their children. In line with Katsa, Sergis, and Sompson [35], flipped classrooms in the technology era provide opportunities for parents and students to collaborate in educating and teaching at home.

\subsubsection{Preparing Learning Materials}

The teacher prepares the material before in class activities. The material has specific characteristics in the flipped classroom [36]. Those characteristics like accessible using technology, easy to learn, and practical used. In addition, the material also be illustrated in various ways, such as viewing on YouTube media or using specific projects [37]. According to Sutama, et al. [38], mathematical concept can be explained with the help of educational games (See Figure 3). 

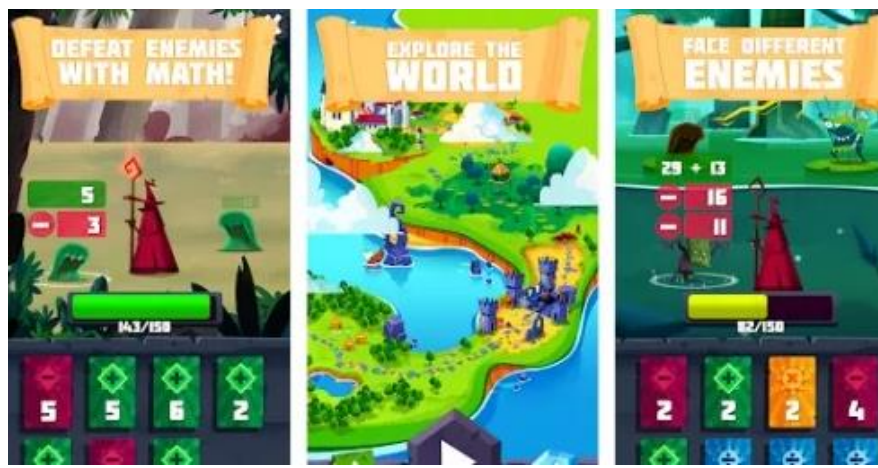

Figure 3. Mathematics Educational Games (source: www.amazon.com)

In addition, many ways used to prepare concepts, such as learning videos [39], virtual teaching [40], educational games [13], project learning [22], and collaboration activities [21]. According to Weingart [41], those methods improve students' critical, elaborative, communication, and creative thinking skills. Furthermore, Birdsall [42], the concepts include questions and directions that stimulate students to explore in further. Giving questions can provide technical guidance for students studying the concept [37]. The last characteristic is the provision of summaries effectively and efficiently [40]. At the end of the concept learning activity, students summarized the recent concepts. It helps teachers' evaluation and control the students' thinking processes.

\subsubsection{Delivering Learning Concepts}

The process of sharing learning concepts employed in modules, notes, or teachers' textbooks [39]. Flipped classroom learning gives teachers much time to provide students modules before class activities — offering notebooks to students to learn [41]. According to Birdsall [42], the teachers notebooks were made concisely, it aimed provide students' focus completely [37]. Meanwhile, teachers may take the media into management learning system [33]. Students asked to access the media by downloading it.

\subsubsection{Monitoring}

According to Wei et al. [30], there are three ways that teachers can do in the monitoring process. Firstly, asking students to make summaries. Giving summary can help teachers understand students' thinking during class activities. In addition, the summary process gives an impression of the quality of students' learning autonomy [21]. Secondly, parents' team work in flipped classroom. The collaboration between parents and teachers in monitoring has effective technique for students' success [20]. In line with Lestari and Noer [34], parents and teachers are two important figures in creating the quality of flipped classroom learning. Lastly, giving students' assignment project. It can help teachers guided students' ability and understand the materials [22].

\subsubsection{Elaboration and Exploration}

Elaboration and exploration were carried out during the situation in the classroom. Based on Makinde [43], during classroom learning, elaboration and exploration can run the class effectively and efficiently. Eka et al. [44], explained that five procedures that teachers can do during the process of elaborating and exploring concepts in the flipped classroom: 1) coherently discussing concepts and starting concepts for the next lesson; 2) expand the concept with maximum reading and explanation; 3) the teachers' answers and responds to students' questions; 4) the teachers' gives students a project to work on as an 
effort to see students' mastery of concepts, and 5) reviewing the concepts that have discussed more detail.

\subsubsection{Evaluation}

Evaluation is an essential activity in the flipped classroom [42]. Evaluation activities can be carried out in several sessions or at the end of the learning session. Evaluation is not only giving tests for the implementation of learning, but also consist of the results of reflections from students and parents [38]. Teachers can ask questions to students and parents about the improvement of flipped classroom activities. However, Oakes et al. [33], the evaluation can also a reflection to improve the quality of the subsequent flipped classroom implementation.

\subsection{Students Activities in Flipped Classroom Mathematics Learning}

Students activities in flipped classroom has two main activities: home activities, and class activities. These activities require good facilities to support the quality of flipped classroom [24].

\subsubsection{Home Activities}

Heeyoung and Ed [45], stated that students home activities are called pre-class activities. These activities consist of the process in learning the concepts, which will be discussed in-class activities. The require abilities that students expected to do in home activities are understand and remember concepts, learning autonomy, and critical thinking.

In learning mathematics, students home activities can illustrate in Figure 4a and $4 \mathrm{~b}$. For instance, teachers' ideas can be accessed in various sources such as YouTube (See figure 4a) or social arithmetic worksheet (See figure $4 b$ ).

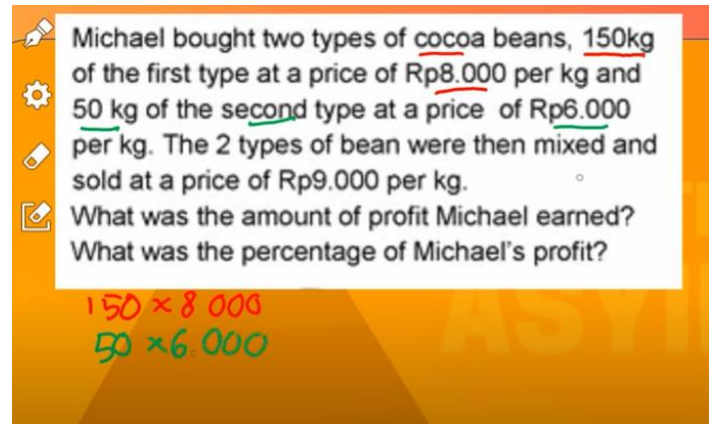

(a)

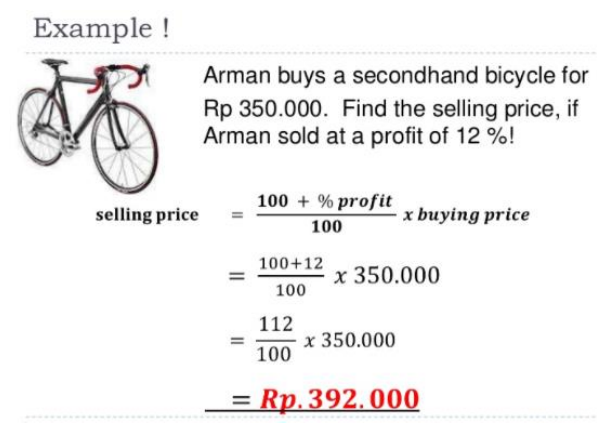

(b)

Figure 4. (a) YouTube (source: www.youtube.com) and (b) Worksheet (source: www.slideshare.net)

\subsubsection{Class Activities}

Student activities in class could be discussion activities and demonstrations of project results. According to Leo [46], there are four student activities during flipped classroom learning in classroom, such as 1) teachers' assignment discussion among students' group; 2) project demonstration results; 3 ) presentation of discussion results and project results; and 4) evaluation. Charles [47], explained that in learning mathematics, discussion of mathematical problems could be applied in peer discussion. For example, in mathematics content of social arithmetic problems, students are discussed those problems in worksheet activity (see Figure $4 b$ ). 
In addition, another activity is project demonstration in mathematics content of determine the profit product (see Figure 5). According to Makinde [43], the project result presentation and discussion in online learning. It is in line with Heeyoung and Ed [45], class activities in the flipped classroom during the pandemic can be occurred in virtual class to adapt to current conditions.

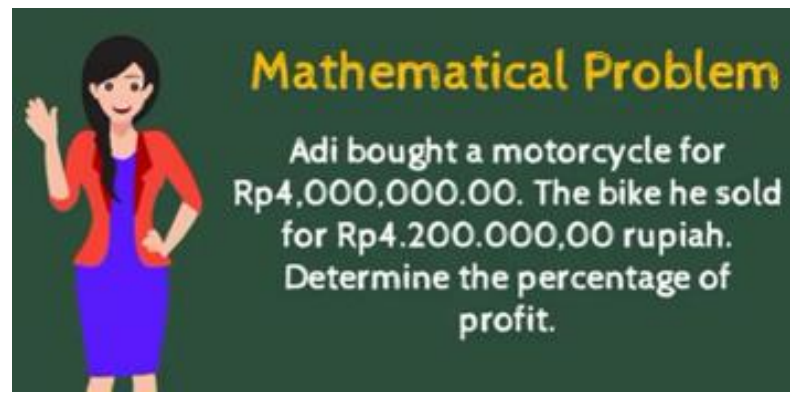

Figure 5. Students' Project Sample (source: www.youtube.com)

Besides, the last activity in class was assignments and evaluation. Evaluation in virtual class could appeared in technology applications such as google classroom or Microsoft Forms [19]. It happened in pandemic situations which do not allow face-to-face meetings. Therefore, whereas face-to-face or virtual class, students' activities in the flipped classroom can pictured effectively.

\subsection{Observation results of Students' Activities in Flipped Classroom}

Based on the observations during flipped classroom learning, it can be explained that student activities while at home and in class can be occurred effectively. Furthermore, it illustrated that the flipped classroom could be an alternative learning in the Society 5.0 era. In detail, the results of observations on flipped classroom activities are as follows:

\subsubsection{The Flipped Classroom Model in an Alternative Today's Learning}

In the Society 5.0 Era, teachers are required to innovate learning [17]. In addition, teachers in technology learning is also necessary to have good digital literacy. It is also in line with the current situation, where learning is applied online. Therefore, flipped classroom is an effective alternative in schools. According to Marsh and Gurski [50], flipped classroom gives students a sense of technology and learning autonomy. In line with Weingart [41], students' digital literacy could increase by implementing a flipped classroom.

\subsubsection{The Flipped Classroom Provide Students' Positive Activities in Home}

Flipped classrooms can encourage positive activities at home. According to Makinde [43], they implement activities at home in a flipped classroom learning such as reading, finding learning resources, and freedom discussion. Moreover, Birdsall [42], explains that students are motivated to freedom learning with the guidance of the teachers' book and parental supervision. Finally, it provided an overview of students' positive activities in home.

\subsubsection{The Flipped Classroom Helps Students Understand the Concept}

Freedom learning in flipped classroom required students to understand the material independently [49]. It led to students' activeness to look for teaching materials and understand concepts actively [18]. According to Makinde [43], students activity of 
understanding the concepts in home could maximized with the role of parents in supervising and teacher guidance. Also, Lestari and Noer [34], explained that the interaction between students and teachers can be employed with active guidance in the teachers' book and pre-learning media. So, in this case, the teacher plays an essential role in providing advice and motivation to students in understanding the concept.

\subsubsection{The Flipped Classroom Guides Students Learn Autonomy}

Flipped classroom helps students to solve problems independently. According to Weippert et al. [16], students assignment and projects could completed separately. However, the projects could do in group learning [20]. Therefore, it provides opportunities for students to work together and collaborate in group learning. Furthermore, the collaborative process in group learning implied benefits for students' interaction [22]. Likewise Makinde [43], freedom learning expressed with group discussions to produce more objective decisions.

Birdsall [42], stated that flipped classroom is suitable applied in this society 5.0 era. However, Charles [47], the application of the flipped classroom required teachers training and preparation, students and parents designing in its implementation. Besides, practice in the flipped classroom required facilities, learning media, technology used, digital literacy, and understanding of learning technology in class [43].

Based on the research, flipped classrooms could improve quality of teaching for 74\% in Egypt [33], 63\% in Singapore [45], and 48\% in South Korea [19]. In line with Wei et al. [33], that flipped classroom can master technology and freedom learning at the same time. Also, Birdsall [42], flipped classroom help students communicate with their groups, solve problems together and discussion learning.

According to Charles [47], flipped classrooms could improve students' critical and creative thinking. The teachers act as a facilitator, while students took their roles in the learning process. The interaction between teachers and students established in the discussion session and assignment. In addition Makinde [43], students can build their ideas and thoughts in learning concepts, the teacher acts as a monitor for the development of students' constructs.

Based on previous studies, flipped classroom has four beneficial: time efficiency [40]; student exploration in broader and deeper [30]; interesting learning in class [35]; and flipped classroom as learning that encourages creativity of teachers and students [34]. According to Thompson [51], with flipped classroom learning, students can manage their study, discuss and present the results of discussions in class. Also, flipped classroom provides opportunities for students to collaborate widely and deeply in the discussion process and learning projects [32]. In addition, flipped classroom process provides a more exciting learning experience and it cannot be separated from the learning media, the technology used, and the discussion process with technology help [36]. Also, flipped classrooms can encourage the creativity of teachers and students. Teachers can increase creativity in the use of technology in the classroom and digital literacy used by students in finding learning resources [31].

In addition, flipped classroom can provide new atmosphere for students in viewing technology [20]. Therefore, teachers must be able to provide the best technology in flipped classroom learning. Sumarni et al. [24], there are six teachers preparation in pre-flipped classroom: 1) using a learning management system in monitoring students learning progress; 2) cooperate with parents in the process of supervising students learning autonomy in home activities; 3) evaluation process periodically; 4) students and parents feedback for the implementation of the next flipped classroom; 5) do reflection with other 
teachers in evaluating the learning process context; and 6) provide assignments and projects (See figure 6).
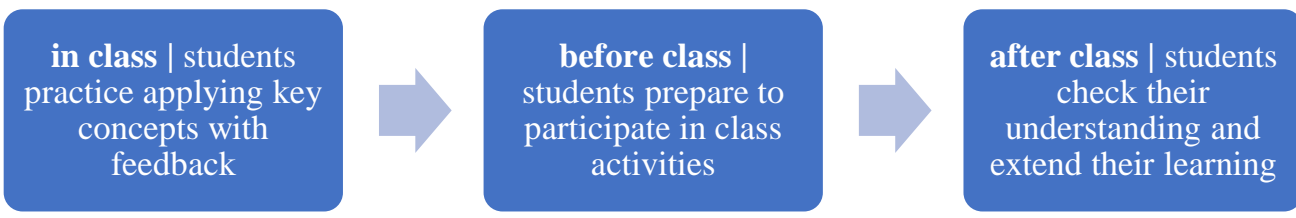

Figure 6. The Flipped Classroom Concepts

Meanwhile, four challenges for teachers implementing flipped classroom. Firstly, students' self-regulation and low motivation. Students' home activities couldn't apply when they have low motivation and bad self-regulation. Therefore, Fung et al. [20], mastering mathematical concepts in flipped classroom learning wouldn't run optimally without students' motivation and self-regulation.

Secondly, mastering teachers time management skills. For example, mathematics concept of social arithmetic requires practice and project to understand the main focus of the concept. Without teachers' time management skills, they couldn't control students' study and time management effectively. Lo and Hew [19], expressed students' concept of social arithmetic mastery could employed through discussion and projects assignment. Besides, understanding the concept of social arithmetic have beneficial in students' daily life [22].

Thirdly, flipped classroom adequate digital literacy of teachers and students [37]. Flipped classroom learning has enormous role in class, so teachers and students must understand how to use technology in their activities [38]. Also, flipped classroom provides an opportunity for teachers to learn digital literacy in preparing learning media [32]. Lestari and Noer [34], time requirement to prepare flipped classroom are essential, the role of technology can help solving those problem. On the other hand, technology for students in flipped classroom also greater. Students' freedom learning in understanding mathematics concepts required technology [36].

Lastly, the implementation of flipped classroom to ensure students learning autonomy. According to Marsh and Gurski [48], teachers must monitor students during out-of-class activities. In this activity, students do the problem-solving assignment in handbook or evaluation learning. These activities require parental monitor. Besides, Ariffuddin et al. [52], teachers' role in monitoring and guiding students could employed in learning management systems and learning outcomes. Both teachers systems guidance help students in learning and solving their problems [30].

Meanwhile, based on the results of interviews, five advantage obtained in flipped classroom learning: 1) the flipped classroom increased interaction among students; 2) flipped classroom changed the way of communicating with parents; 3) flipped classroom provides knowledge to parents; and 4) flipped classroom provides opportunities for students to find several learning resources; and 5) flipped classroom improve students' digital literacy. According to Katsa et al. [35], the relationship among students in discussion could occurred by technology, such as zoom-meeting applications, googlemeet, etc. Also, Birdsall [42], students interactions provide opportunities to improve their critical thinking skills, and respect differences of opinion.

On the other hand, home activities for students encourage the intensity of the communication between students and parents. Makinde [43], positive interactions could build between students and parents in understanding concepts and managing time. Besides, 
Weinhandl, et al. [23], explained that teachers could be a mediator between students and parents during home activities. This interaction can increase the positive relationship between students and parents. Furthermore, mastery of technology helps them cooperate and trust in each other [24].

Subsequently, flipped classroom provide good technology knowledge to parents. The technology knowledge possessed as a reference for improving the quality of student learning at home activities [19]. Gaining parents knowledge increase students achievement in their freedom learning [49]. So, it can be explained that flipped classroom has a role in increasing students' digital literacy as well.

Birdsall [42], confirmed four aspects in implementing flipped classroom:1) flexible environment, 2) learning culture, 3) intentional content, and 4) professional teachers. In flexible environment, every teacher must prepare a time and be good attention person for their students. Also, teachers' time management in flipped classroom consist of three activities: pre-class, in-class and out of-class activities. According to Pardimin et al. [22], pre-class activities expressed students freedom learning in home. Whereas in-class activities occurred students discussion and project presentation. Then out of-class activities included teachers' supervision in students project work and assignment process.

Therefore, in this study, flipped classrooms employed a good learning culture. The learning culture expressed students learning autonomy: understand the concepts, and provide opportunities for students to discuss with workgroups. Besides, teachers' digital literacy engages learning media and technological knowledge for students' freedom learning, it was express intentional content of flipped classroom. The last aspect in flipped classroom is the professional teachers. Be professional teachers require teachers as guider and assessor for student activities in flipped classroom. Also, teachers be good collaboration with parents in assessing students home activities. This collaborative process can be an opportunity for parents to interact positively with students.

\section{CONCLUSION}

The flipped classroom has beneficial in increasing students' digital literacy in the era of society 5.0. The role of technology in flipped classroom learning provide an overview of the quality of learning using technology. Mastery of the class and proficiency in using technology for teachers were the essentials in adapting flipped classroom. In addition, digital literacy allowed teachers explore learning with technology collaboration and digital interactive-based media. Furthermore, implementing flipped classroom employed three activities, pre-class, in-class, and out of-class activities. The technology used in finding learning resources, discussing with study groups, and doing project assignments are other beneficials of flipped classroom. In addition, students' critical and creative thinking could improve. Critical and creative thinking employed in understanding the concepts and problems with worksheet or project assignment. Creative thinking also used in discussions. Flipped classroom also provide opportunities for parents to interact with students in home activities. Therefore, flipped classroom learning could the alternative learning in the society 5.0 era and could increase the role of technology in classroom learning.

\section{REFERENCES}

[1] C. A. Archiyesa, "Education Strategy towards Digital Competences in Welcoming Society 5.0," J. Basic Educ., vol. 4, no. 3, pp. 33-45, 2019.

[2] E. Aprilisa, "Realizing Society 5.0 to Face the Industrial Revolution 4.0 and Teacher Education Curriculum Readiness in Indonesia," Proceeding Int. Conf. Sci. Eng., vol. 3, no. April, pp. 543-548, 2020, doi: 10.14421/icse.v3.559. 
[3] R. Novita and T. Herman, "Digital technology in learning mathematical literacy, can it helpful?," J. Phys. Conf. Ser., vol. 1776, no. 1, pp. 554-563, 2021, doi: 10.1088/1742-6596/1776/1/012027.

[4] C. Narvaez Rojas, G. A. Alomia Peñafiel, D. F. Loaiza Buitrago, and C. A. Tavera Romero, "Society 5.0: A Japanese Concept for a Superintelligent Society," J. Emerg. Trends Educ. Res. Policy Stud., vol. 13, no. 12, pp. 65-72, 2021, doi: 10.3390/su13126567.

[5] Nurhastuti, "Pendidikan Matematika Pada Era Society 5.0," J. Ilm. Pendidik. Mat., vol. 3, no. 22, pp. 11-26, 2019.

[6] R. Perdana, R. Yani, J. Jumadi, and D. Rosana, "Assessing Students' Digital Literacy Skill in Senior High School Yogyakarta," JPI (Jurnal Pendidik. Indones., vol. 8, no. 2, p. 169, 2019, doi: 10.23887/jpi-undiksha.v8i2.17168.

[7] Pagina Thomson, "Higher order thinking skills in mathematics learning," $J . A d v$. Res. Des., vol. 15, no. 2, p. 1, 2019, doi: http://www.jstor.org/stable/1175860.

[8] C. J. Maker, S. Jo, and O. M. Muammar, "Development of creativity: The influence of varying levels of implementation of the ICT Literacy, a non-traditional teacher beliefs," Learn. Individ. Differ., vol. 18, no. 4, pp. 402-417, 2018, doi: 10.1016/j.lindif.2008.03.003.

[9] A. Supendi and Nurjanah, "Society 5.0:Is It High-Order Thinking?," Glob. Perspect. 21st Elem. Educ., vol. 2, no. 1, pp. 1054-1059, 2019.

[10] T. Abel, J. Brazas, D. C. Jr, and A. Kemp, "Characterizing Mathematical Digital Literacy: A Preiminary Investigation,” J. Curric. Instr., vol. 4, no. 2, pp. 421-430, 2018.

[11] S. P. van Borkulo, M. Kallia, P. Drijvers, E. Barendsen, and J. Tolboom, "Computational thinking and mathematical thinking: Digital literacy in mathematics curricula," Proc. 14th Int. Conf. Technol. Math. Teach. - ICTMT 14, vol. 6, no. October, pp. 384-386, 2019.

[12] A. J. Toha Tohara, F. D. Mohamed Shuhidan, Shamila Saiful Bahry, and M. N. Nordin, "Exploring Digital Literacy Strategies for Students with Special Educational Needs in the Digital Age," Turkish J. Comput. Math. Educ., vol. 12, no. 9, pp. 3345-3358, 2021.

[13] M. Novitasari, Sutama, S. Narimo, A. Fathoni, L. Rahmawati, and C. Widyasari, "Habituation of digital literacy and critical thinking in mathematics in elementary school," Int. J. Sci. Technol. Res., vol. 9, no. 3, pp. 3395-3399, 2020.

[14] A. Fatahillah, I. D. Puspitasari, and S. Hussen, "The development of Schoology web-based learning media with GeoGebra to improve the ICT literacy on quadratic functions," JRAMathEdu (Journal Res. Adv. Math. Educ., vol. 5, no. 3, pp. 304316, 2020, doi: 10.23917/jramathedu.v5i3.10692.

[15] L. Naismith, P. Lonsdale, G. Vavoula, and M. Sharples, "Literature Review in Mobile Technologies and Learning," J. Educ. Comput. Res., vol. 8, no. 4, pp. 3144, 2016.

[16] S. Weippert, Achim and Kajewski, "Internet-based Information and Communication Systems - A Case Study Analysis," J. Basic Educ., vol. 2, no. 2, pp. 103-116, 2017, doi: 10.1016/S0261-5177(02)00005-5.

[17] N. Vinoth and K. Nirmala, "Deaf Students Higher Education System Using ELearning," J. Educ. Learn., vol. 11, no. 1, p. 41, 2017, doi: 10.11591/edulearn.v11i1.5131.

[18] J. Voogt, O. Erstad, C. Dede, and P. Mishra, "Challenges to learning and schooling in the digital networked world of the 21st century," J. Comput. Assist. Learn., vol. 
29, no. 5, pp. 403-413, 2020, doi: 10.1111/jcal.12029.

[19] C. K. Lo and K. F. Hew, "A critical review of flipped classroom challenges in K-12 education: possible solutions and recommendations for future research," Res. Pract. Technol. Enhanc. Learn., vol. 12, no. 1, pp. 22-35, 2017, doi: 10.1186/s41039-0160044-2.

[20] C. H. Fung, M. Besser, and K. K. Poon, "Systematic Literature Review of Flipped Classroom in Mathematics," Eurasia J. Math. Sci. Technol. Educ., vol. 17, no. 6, pp. 1-17, 2021, doi: 10.29333/ejmste/10900.

[21] Z. Cramer, "Active Learning and Flipped Classrooms in Introductory Mathematics Centre for Teaching Excellence Table of Contents," J. Math. Sci. Math. Educ., vol. 1, no. 3, pp. 34-46, 2020.

[22] Pardimin, S. Rochmiyati, Z. Wijayanto, and D. Supriadi, "A Needs Analysis of Flipped Classroom -Based Mathematics Learning Model," PalArch's J. Archaeol. Egypt/Egyptology, vol. 17, no. 5, pp. 69-94, 2020.

[23] R. Weinhandl, Z. Lavicza, M. Hohenwarter, and S. Schallert, "Enhancing flipped mathematics education by utilising GeoGeBrA," Int. J. Educ. Math. Sci. Technol., vol. 8, no. 1, pp. 1-15, 2020, doi: 10.46328/IJEMST.V8I1.832.

[24] R. A. Sumarni, Y. B. Bhakti, I. A. D. Astuti, D. Sulisworo, and M. Toifur, "The Development of Animation Videos Based Flipped Classroom Learning on Heat and Temperature Topics," Indones. J. Sci. Math. Educ., vol. 3, no. 3, pp. 304-315, 2020, doi: 10.24042/ijsme.v3i2.7017.

[25] A. M. Ruswana, "Applicatıon Of Flipped Classroom Learnıng Models With Peer Instruction Flipped Type To Improve The Mathematical Problems Solving Ability Of Pre- Prosperous Students," J. Inov. Pendidik. Mat., vol. 7, no. 2, pp. 168-183, 2019.

[26] J. W. Creswell, Research Design: Qualitative, Quantitative, and Mixed Method. 2014

[27] L. Cohen, L. Manion, and K. Morrison, Research Methods in Education Sixth Edition. 2013.

[28] K. Umam, T. Nusantara, I. N. Parta, E. Hidayanto, and H. Mulyono, "An application of flipped classroom in mathematics teacher education programme," Int. J. Interact. Mob. Technol., vol. 13, no. 3, pp. 68-80, 2019, doi: 10.3991/ijim.v13i03.10207.

[29] L. R. Hidayah and A. Mustadi, "The Implementation of the Flipped Classroom for Early Grade Students in Elementary School," J. Math. Stat., vol. 5, no. 1, pp. 98106, 2021.

[30] X. Wei et al., "Effect of the flipped classroom on the mathematics performance of middle school students," Educ. Technol. Res. Dev., vol. 68, no. 3, pp. 1461-1484, 2020, doi: 10.1007/s11423-020-09752-x.

[31] L. Jin, "The Flipped Classroom Approach in Calculus Teaching with Mathematics Software," J. Res. Inf. Technol., vol. 13, no. 5, pp. 168-170, 2019, doi: 10.2991/ssphe-18.2019.40.

[32] E. Apriska and Sugiman, "Flipped classroom research trends in mathematics learning in Indonesia," J. Phys. Conf. Ser., vol. 1613, no. 1, pp. 33-47, 2020, doi: 10.1088/1742-6596/1613/1/012030.

[33] D. Oakes, A. Davies, M. Joubert, and S. Lyakhova, "Exploring teachers' and students' responses to the use of a Flipped Classroom teaching approach in mathematics," BSRLM Proceedings, King's Coll. London 38(3), vol. 38, no. November, pp. 1-6, 2018.

[34] B. Lestari and S. Noer, "The Learning Strategy of The Flipped Classroom With 
Gamification As An Alternative Learning Solution During The Covid-19 Pandemic," J. Teach. Phys. Educ., vol. 4, no. 3, pp. 54-66, 2021, doi: 10.4108/eai.16-10-2020.2305193.

[35] M. Katsa, S. Sergis, and D. G. Sampson, "Investigating the potential of the flipped classroom model in K-12 mathematics teaching and learning," 13th Int. Conf. Cogn. Explor. Learn. Digit. Age, vol. 4, no. 3, pp. 210-218, 2016.

[36] Ramakrishnan and JohnsiPriya, "Effectiveness of Flipped Classroom in Mathematics Teaching," Int. J. Res. Educ. Sci., vol. 4, no. 10, pp. 57-62, 2018, doi: 10.29121/granthaalayah.v4.i10(se).2016.2469.

[37] R. A. Efiuvwere and E. F. Fomsi, "Flipping the Mathematics Classroom to Enhance Senior Secondary Students Interest," Int. J. Math. Trends Technol., vol. 65, no. 2, pp. 95-101, 2019, doi: 10.14445/22315373/ijmtt-v65i2p516.

[38] Sutama, H. J. Prayitno, N. Ishartono, and D. P. Sari, "Development of Mathematics Learning Process by Using Flipped Classroom Integrated by STEAM Education in Senior High School," Univers. J. Educ. Res., vol. 8, no. 8, pp. 3690-3697, 2020, doi: 10.13189/ujer.2020.080848.

[39] A. Rafiepour, "Effect of Flipped Classroom Teaching Method on Learning of Mathematics of Grade 7 Female Students," J. Elem. Sci. Educ., vol. 15, no. 57, pp. 129-154, 2020.

[40] Y. Deliktaş and I. Stojkovska, "Investigating the impact of flipped learning on mathematics performance and math anxiety," J. Emerg. Trends Educ. Res. Policy Stud., vol. 4, no. 3, pp. 27-37, 2019.

[41] M. Weingart, "Flipping the classroom in Rutgers Mathematics Courses," J. Appl. Quant. Methods, vol. 4, no. 2, pp. 55-69, 2019.

[42] A. Birdsall, "Investigating the potential of the Flipped Classroom Model," J. Educ. Technol. Soc., vol. 5, no. 3, pp. 1-27, 2017.

[43] S. O. Makinde and H. Article, "Mass Media as a Change Agent on Childhood Social Pedagogy and Achievement," Indones. J. Early Child. Influ. Soc., vol. 9, no. 1, pp. $1-7,2020$.

[44] S. Eka, E. Purba, K. B. Sangka, and O. K. Hussain, "The Flipped Classroom : An Overview of its Impact on Economics Learning," Educ. Res. Int., vol. 5, no. 1, pp. 26-34, 2021.

[45] J. Heeyoung and K. Ed, "Examining the Flipped Classroom Model through Literacy and Math Integration," J. Educ. Technol. Dev. Exch., vol. 5, no. 3, pp. 55-68, 2019.

[46] C. Leo, "Flipped Classroom Pedagogical Model and Middle-Level Mathematics Achievment : An Action Research Study," J. Int. Dev., vol. 4, no. 2, pp. 553-563, 2017.

[47] G. Charles, "Flipped Classroom Model : Effects on Performance, Attitudes and Perceptions in High School Algebra," J. Math. Teach. Educ., vol. 4, no. 6, pp. 33 47, 2016, doi: 10.1007/978-3-319-45153-4.

[48] S. Marsh and N. Gurski, "Flipped teaching as a method for boosting engagement and performance," J. Emerg. Trends Educ. Res. Policy Stud., vol. 4, no. July, pp. 556-568, 2016.

[49] F. D. Fernández-Martín, J. M. Romero-Rodríguez, G. Gómez-García, and M. R. Navas-Parejo, "Impact of the flipped classroom method in the mathematical area: A systematic review," Math. Educ. Res. J., vol. 8, no. 12, pp. 1-11, 2020, doi: $10.3390 /$ math8122162.

[50] A. Sofian, E. Hidayat, W. Fitri, and A. Wihdati, "Dealing with Challenges in Teaching \& Learning Mathematics in Flipped Classroom Model in Pandemic Era," 
J. Res. Math. Educ., vol. 550, no. Icmmed 2020, pp. 47-54, 2021.

[51] P. W. Thompson, "Technology in Mathematics Education Research: The First 25 Years in the JRME," Res. Math. Educ., vol. 4, no. December 1994, pp. 22-39, 2014, doi: $10.2307 / 749579$.

[52] M. Ariffuddin et al., "The Implementation of Flipped Classroom Instructional to Enhance Academic Achievement among form Four Chemistry Students," Int. J. Acad. Res., vol. 9, no. 7, pp. 967-980, 2019, doi: 10.6007/IJARBSS/v9-i7/6195. 